\title{
Comparing Risks and Benefits for the Value Enhancement of Online Purchases
}

\author{
Priyanka Sinha, ${ }^{1 *}$ and Saumya Singh ${ }^{2}$ \\ ${ }^{1}$ Institute of Innovation in Technology and Management, New Delhi \\ ${ }^{2}$ Indian Institute of Technology, Dhanbad
}

\begin{abstract}
In a developing economy, the acceptability of e-retailing is not very new, but the potential of online marketing in market research and analysis is still largely unexplored. This article is an attempt to understand the psyche of Indian online consumers. As consumers have their own preconceived notions toward this growing purchasing environment, it becomes important for e-retailers to understand the consumers' perceptions and attitudes toward online purchases. This paper integrates the dimensions of the risks and benefits with the Theory of Planned Behavior (TPB) to understand how consumers adopt their online purchase processes. Four hundred and sixty-eight valid responses were analyzed using structural equation modeling on AMOS 21 to identify the relationship between the different factors and the intention to purchase online. The paper concludes that consumers' purchase intentions are jointly determined by their attitude towards online purchases and the subjective norm. Furthermore, their attitude is determined by the sub-dimensions of perceived benefits (hedonic benefit, convenience benefit, economic benefit and variety) and the sub-dimensions of perceived risk (product risk and financial risk).
\end{abstract}

Keywords: consumer perception; online purchase; perceived benefit; perceived risk; TPB

JEL classification: M31

* Corresponding author's e-mail: sinha.priyanka09@gmail.com 


\section{Introduction}

From being merely used as jargon to the present reality, e-commerce in India has been experiencing unprecedented growth. The Indian e-commerce market was worth about $\$ 3.8$ billion in 2009 , it went up to $\$ 17$ billion in 2014 and to $\$ 23$ billion in 2015 and is expected to touch $\$ 38$ billion, a 67 percent jump over the last year in 2016 (The Hindu 2016). However, as per the industry experts, this is just the beginning of the e-commerce wave in India and it is going to witness a new world of digitization in the decade to come. A host of investors around the world are keenly awaiting the opportunities to capitalize on this potential market which makes understanding Indian consumers' purchasing behavior and their attitude towards the online market even more crucial.

As mentioned by Bhatnagar and Ghosh (2004) a consumer compares the risks and benefits associated with a purchase decision and opt for the one that can maximize his/ her total purchase value. Various researchers in the past have tried to identify the factors that influence consumers' intentions to shop online (Chen and Li 2009; Childers et al. 2001; Dillon and Reif 2004; Moshrefjavadi et al. 2012; Simonian et al. 2012; Verhoef and Langerak 2001). However, very few research works have simultaneously included factors that motivate (perceived benefits) and prevent (perceived risk) consumers shopping online in a single study. Moreover, there is a scarcity of empirical work done in the Indian context. The Theory of Planned Behavior (TPB), (Aizen 1991) is one of the most established theories in the area of consumer behavior and has been used by various researchers in the past to predict consumers' purchase intentions (Kalafatis et al. 1999; Pavlou and Fygenson,2006; Shih et al. 2004)
. This paper integrates the perceived risk and perceived benefit of online purchases with the theory of planned behavior so as to formulate a better theoretical basis to examine the consumers' adoption of online purchasing.

This section is followed by a literature review, which is subsequently followed by the research methodology, data collection, the findings and lastly the implications.

\section{Literature Review}

\section{Perceived Risk in Online Purchase}

Researchers on consumers' online purchase behavior have consistently confirmed that different types of risks inhibit the consumers' decisions to shop online. Forsythe and Shi (2003) identified 18 different types of risks that differentiate internet browsers (term used by the researcher for consumers who enjoy internet surfing but do not shop online) from online shoppers when contemplating a particular online purchase decision. Product performance risk, financial risk, time/convenience risk and privacy issues were rated as the top concerns in the research. Claudia (2012) classified the perception of online risk according to its intensity, and claimed that the financial risk that is due to credit card fraud is the biggest fear of the respondents. The fear that a product will not perform as promised was the second most common fear among respondents. Time lost in waiting for the product to reach its destination, or in returning a product that has failed to perform as promised, was rated as the third common fear among consumers. The risk of non delivery, privacy risk, psychological risk and social risk were rated thereafter as per their intensity. One other study of UK con- 
sumers by Al Karim (2013) identified that online payment systems, personal privacy or security issues, delays in delivery; products being mixing up in delivery, product return policies and the lack of personal control are the main inhibitors to online purchases. However, the delivery risks and risks with the online payments were identified as the most important concerns.

The perceived risk seems to be the most researched variable in the context of online purchases (Chang et al. 2005). However, the findings of their impact on the attitude/intention to use are mixed, as indicated in Table (1). This may be because of cultural and economical differences, or difference in the respondent's demographic characteristics. This paper helps understand the impact of four major sub-dimensions of perceived risk, which are: Financial risk, product risk, time risk and the risk of non delivery for India's young consumers when purchasing retail products online.

\section{Perceived Benefit of Online Purchase}

The perceived benefits associated with online purchases are the motivating factors that attract consumers to shop online (Childers et al. 2001; Lee 2009; Kim and Kim 2004; Keeney 1999; Reibstein 2002). As claimed by Darian (1987) home purchase comprises of a reduction in the purchase time, a reduction in the physical effort to visit a store and flexibility in the purchase time. Therefore, consumers' who value conve-

Table 1. Dimensions of Risk and Its Impact on the Attitude/Intention to Online Shop

\begin{tabular}{|c|c|c|c|}
\hline $\begin{array}{l}\text { Dimension } \\
\text { of Online } \\
\text { Risk }\end{array}$ & Definition & $\begin{array}{c}\text { Impact } \\
\text { on Attitude/ } \\
\text { Intention } \\
\text { to Shop Online }\end{array}$ & Reference \\
\hline Financial Risk & $\begin{array}{l}\text { Risk of losing money due to } \\
\text { credit card fraud, disclosure } \\
\text { of bank account } \\
\text { information, being } \\
\text { overcharged or due to the } \\
\text { purchase of the wrong } \\
\text { product }\end{array}$ & No impact & $\begin{array}{l}\text { Almousa 2011; Bhatnagar and } \\
\text { Ghosh 2004; Crespo et al. 2009; Lu, } \\
\text { Hsu, and Hsu 2005; Lee 2009; } \\
\text { Maignan and Lukas 1997; } \\
\text { Moshrefjavadi, et al. 2012. } \\
\text { Zhang et al. 2012; }\end{array}$ \\
\hline Product risk & $\begin{array}{l}\text { Risk of product not } \\
\text { performing as expected }\end{array}$ & Negative & $\begin{array}{l}\text { Bhatnagar and Ghose 2004; } \\
\text { Bhatnagar et al. 2000; Crespo et al. } \\
\text { 2009; Lu et al. 2005; Lee 2009; } \\
\text { Moshrefjavadi et al. } 2012 .\end{array}$ \\
\hline & & No Impact & Almousa 2011; Zhang et al. 2012. \\
\hline $\begin{array}{l}\text { Risk of time } \\
\text { loss }\end{array}$ & $\begin{array}{l}\text { Loss of time browsing } \\
\text { websites to find and } \\
\text { purchase suitable products }\end{array}$ & Negative impact & $\begin{array}{l}\text { Crespo et al. 2009; Moshrefjavadi, et } \\
\text { al. 2012; Masoud } 2013 . \\
\text { Almousa 2011; Lee 2009; Zhang et } \\
\text { al. 2012. }\end{array}$ \\
\hline Delivery risk & $\begin{array}{l}\text { Risk of non delivery or } \\
\text { delivery of damaged } \\
\text { products }\end{array}$ & Negative & $\begin{array}{l}\text { Moshrefjavadi, et al. 2012; Zhang et } \\
\text { al. 2012; }\end{array}$ \\
\hline
\end{tabular}


nience are more inclined toward the online purchase (Swaminathan et al. 1999; Prasad and Aryasri 2009). Apart from providing convenience to their consumers, online shops also provide them with a huge variety of products (Clemes et al. 2013). As identified by Chiang and Dholakia (2003) consumers are motivated to shop online as they believe that online stores can provide them with products that are not easily available in local retail stores.

The perceived benefits of online purchasing are also claimed to be multidimensional. These dimensions include utilitarian benefits like product offerings (Jarvenppa and Todd 1996; Machlis 1999), product information (Mayasar 2012) convenience (Bhatnagar and Ghosh 2004; Swaminathan et al. 1999), cost savings (Miller 2000; Su and Huang 2011) and enjoyment or playfulness aspects (Forsythe et al. 2006, Hoffman and Novak 1996). Forsythe et al. (2006) has identified four dimensions of perceived benefits, they are: Purchase convenience, product selection, ease or comfort of buying and hedonic/enjoyment. Ramus and Nielsen (2005) further added information availability, social aspects, personal service, and price/bargains to the four dimensions of the scale by Forsythe et al. Dabhade (2008) suggested that items under the purchase convenience and ease or comfort of buying by Forsythe et al. (2006) can be grouped under a single component, while dimensions like product selections identified by Forsythe et al. (2006) and availability of products, product information and the

Table 2. Dimensions of Perceived Benefit and Its Impact on Attitude/Intention to Online Shop

\begin{tabular}{|c|c|c|c|}
\hline $\begin{array}{l}\text { Dimension } \\
\text { of Online } \\
\text { Risk }\end{array}$ & Definition & $\begin{array}{l}\text { Impact } \\
\text { on Attitude/ } \\
\text { Intention } \\
\text { to Shop Online }\end{array}$ & Reference \\
\hline Financial Risk & $\begin{array}{l}\text { Risk of losing money due to } \\
\text { credit card fraud, disclosure } \\
\text { of bank account } \\
\text { information, being } \\
\text { overcharged or due to the } \\
\text { purchase of the wrong } \\
\text { product }\end{array}$ & No impact & $\begin{array}{l}\text { Almousa 2011; Bhatnagar and } \\
\text { Ghosh 2004; Crespo et al. 2009; Lu, } \\
\text { Hsu, and Hsu 2005; Lee 2009; } \\
\text { Maignan and Lukas 1997; } \\
\text { Moshrefjavadi, et al. 2012. } \\
\text { Zhang et al. 2012; }\end{array}$ \\
\hline Product risk & $\begin{array}{l}\text { Risk of product not } \\
\text { performing as expected }\end{array}$ & Negative & $\begin{array}{l}\text { Bhatnagar and Ghose 2004; } \\
\text { Bhatnagar et al. 2000; Crespo et al. } \\
\text { 2009; Lu et al. 2005; Lee 2009; } \\
\text { Moshrefjavadi et al. } 2012 \text {. }\end{array}$ \\
\hline & & No Impact & Almousa 2011; Zhang et al. 2012. \\
\hline $\begin{array}{l}\text { Risk of time } \\
\text { loss }\end{array}$ & $\begin{array}{l}\text { Loss of time browsing } \\
\text { websites to find and } \\
\text { purchase suitable products }\end{array}$ & No Sig. Impact & $\begin{array}{l}\text { Crespo et al. 2009; Moshrefjavadi, et } \\
\text { al. 2012; Masoud } 2013 . \\
\text { Almousa 2011; Lee 2009; Zhang et } \\
\text { al. } 2012 .\end{array}$ \\
\hline Delivery risk & $\begin{array}{l}\text { Risk of non delivery or } \\
\text { delivery of damaged } \\
\text { products }\end{array}$ & Negative & $\begin{array}{l}\text { Moshrefjavadi, et al. 2012; Zhang et } \\
\text { al. 2012; }\end{array}$ \\
\hline
\end{tabular}


bargain purchases identified by Ramus and Nielsen (2005) can be clubbed together into another component. Thus, the research identified three components of perceived benefits, namely: Purchase convenience, product and price offering and enjoyment/hedonic. This paper treats product and price offerings as two different components and focuses on four major dimensions of perceived benefit, namely: Convenience, economic benefit/price offerings, product offerings/variety and enjoyment/hedonic benefit. Table (2) indicates previous studies exploring the relation between various sub-dimensions of perceived benefits and the attitude or intention towards online purchasing.

\section{Theory of Planned Behavior}

The Theory of Planned Behavior (TPB) by Aizen (1991) is an extension of the Theory of Reasoned Action (TRA) (Ajzen and Fishbein 1980; Fishbein and Ajzen 1975) and was developed to explain TRA by adding perceived behavioral control as a factor influencing both the behavior and intention. According to the behavioral model, intention is the direct antecedent of the actual behavior. Behavioral intention is defined as an individual's likelihood of engaging in the behavior of interest, and it is a function of three components namely: Attitude, subjective norms and perceived behavioral control.

Attitude is the positive or negative vibes of an individual regarding the consequence of performing a behavior (Fishbein and Aizen 1975). Attitude is the individual's evaluation of the behavior in question and differs from person to person. According to TRA, a person's attitude towards his behavior is based on his or her belief about the consequence of performing a given behavior multiplied by their evaluation of these consequences.
Subjective Norms are the normative beliefs that refer to the individual's perception about what a specific group of people, or people important to him/her, may think about whether he should or should not perform the behavior in question. The subjective norm is based on two factors, the belief about the perceptions of others and the motivation to comply with them.

Perceived Behavioral Control (PBC): - The PBC plays an important part in the theory of planned behavior and is the key concept that differentiates it from the theory of reasoned action. The PBC refers to the people's perception of the ease or difficulty of possessing the resources and opportunities needed to engage in a behavior (Aizen 1991). For example if two individuals have a strong intention to learn a new language, the one who thinks that he/she will succeed in mastering itwill persevere hard than the other who doubts his/her capabilities (Aizen 1991).

\section{Conceptual Framework and Hypotheses Development}

The study merges the theory of planned behavior with dimensions of the perceived risk and perceived benefit to formulate the research model (Figure 1) and its associated hypotheses. According to this model, three constructs have a significant impact on intention to shop for retail products online (the subjective norm, perceived behavioral control and attitude), and to experience products online (the subjective norm, perceived behavioral control and attitude). Whereas, the attitude towards using an online medium for purchase is determined by the consumer's perception of the risks and benefits associated with online purchases. 


\section{Hypothesis regarding financial risk}

Financial risk in the online context is defined as the risk of losing a certain amount of money due to credit card fraud (Maignan and Lukas 1997; Pallab 1996). Various researchers in the past have claimed that the financial risk inversely impacts the consumer's attitude toward online purchases (Almousa 2011; Javadi et al. 2012). Masoud 2013 and Sinha and Singh 2013 identified that the risk of losing money, or the probability of disclosing credit card information is an important factor for not purchasing online. Therefore we can hypothesize:

$H_{1 a}$ : Financial risk has a significant negative impact on the consumer's attitude toward online purchases.

\section{Hypothesis regarding product risk}

Product risk can be defined as the fear of the non performance of a product. In the words of Bhatnagar et al. (2000), product risk is more prominent in online purchasing due to the inability of the buyers to accurately examine the physical qualities of the product. Difficulty in judging the quality of a product on the internet is a significant factor that negatively impacts the consumers' attitudes toward online purchasing (Bhatnagar and Ghosh 2004; Bhatnagar et al. 2000; Crespo et al. 2009; Lu et al. 2005; Lee 2009; Moshrefjavadi et al. 2012; Masoud 2013). Hence we can hypothesize:

$H_{1 b}$ : Product risk has a significant negative impact on the consumer's attitude toward online purchases.

\section{Hypothesis regarding time risk}

Forsythe et al. (2006), defined the time risk in the context of online purchases as the inconvenience or time lost in navigating across sites, locating appropriate sites or prod- ucts or in submitting orders. Consumers who are new to online purchasing find problems in locating appropriate sites or with online ordering (Almousa 2011; Lee 2009; Forsythe and Shi 2003), and hence perceive online purchasing to be time consuming. Hence, we can hypothesize:

$H_{1:}$ Time risk has a significant negative impact on
the consumer's attitude toward online purchases.

Hypothesis regarding delivery risk

Delivery risk is the potential loss of goods in transit, or the delivery of the goods in an improper condition, or at an improper place or time (Dan et al. 2007). Because of the virtual nature of online shops and there being very little trust in online retailers, the delivery risk is a significant concern among consumers, and has a negative impact on their attitude toward online purchases (Alkailani and Kumar 2011; Masoud 2013; Zhang et al. 2012).

\section{$H_{1 \dot{0}}$ Delivery risk has a significant negative impact on the consumer's attitude toward online pur- chases.}

\section{Hypothesis regarding convenience}

Convenience is regarded as one of the most important motivators in a consumer's decision to shop online. As defined by Darian (1987) convenience in home purchasing comprises of a reduction in the purchase time, a reduction in the physical effort involved in visiting a store and flexibility in the purchase time, Various researchers in the past have claimed that consumers who value convenience are more inclined towards online purchases (Swaminathan et al. 1999, Prasad and Aryasri 2009). Clemes et al. (2013) also identified that convenience is pertinent to the acceptance of online stores, as with online 
purchases consumers need not be worried about parking, transportation or the weather conditions. Therefore we hypothesize:

$H_{2 a}$ : Convenience has a significant positive impact on the consumer's attitude toward online purchases.

\section{Hypothesis regarding economic benefit}

Reibstein (2002) claimed that online consumers make price comparisons across various online sites before making a purchase decision. Online consumers are price sensitive and treat discounts or offers available on the websites as a compensation for the risk they take in purchasing from a virtual medium (Childers et al. 2001; Kim and Kim 2004). Therefore:

$H_{2 b}$ : Economic benefit has a significant positive impact on the consumer's attitude toward online purchases.

\section{Hypothesis regarding product variety}

Keeney (1999) identified that consumers prefer to compare the attributes of the different varieties of products available, to make better purchasing decisions. Clemes et al. (2013) identified that product variety plays a significant role in the acceptance of the internet as a purchase medium. Chiang and Dholakia (2003) claimed that consumers are oriented toward online stores as they believe that online stores can provide them with those products that are not easily available in their local retail stores. Lee (2009) claimed that the variety offered by online stores brings consumers to shop online. Therefore:

$H_{2 i}$ : Product variety has a significant positive impact on the consumer's attitude toward online purchases.

Figure 1. Conceptual Framework

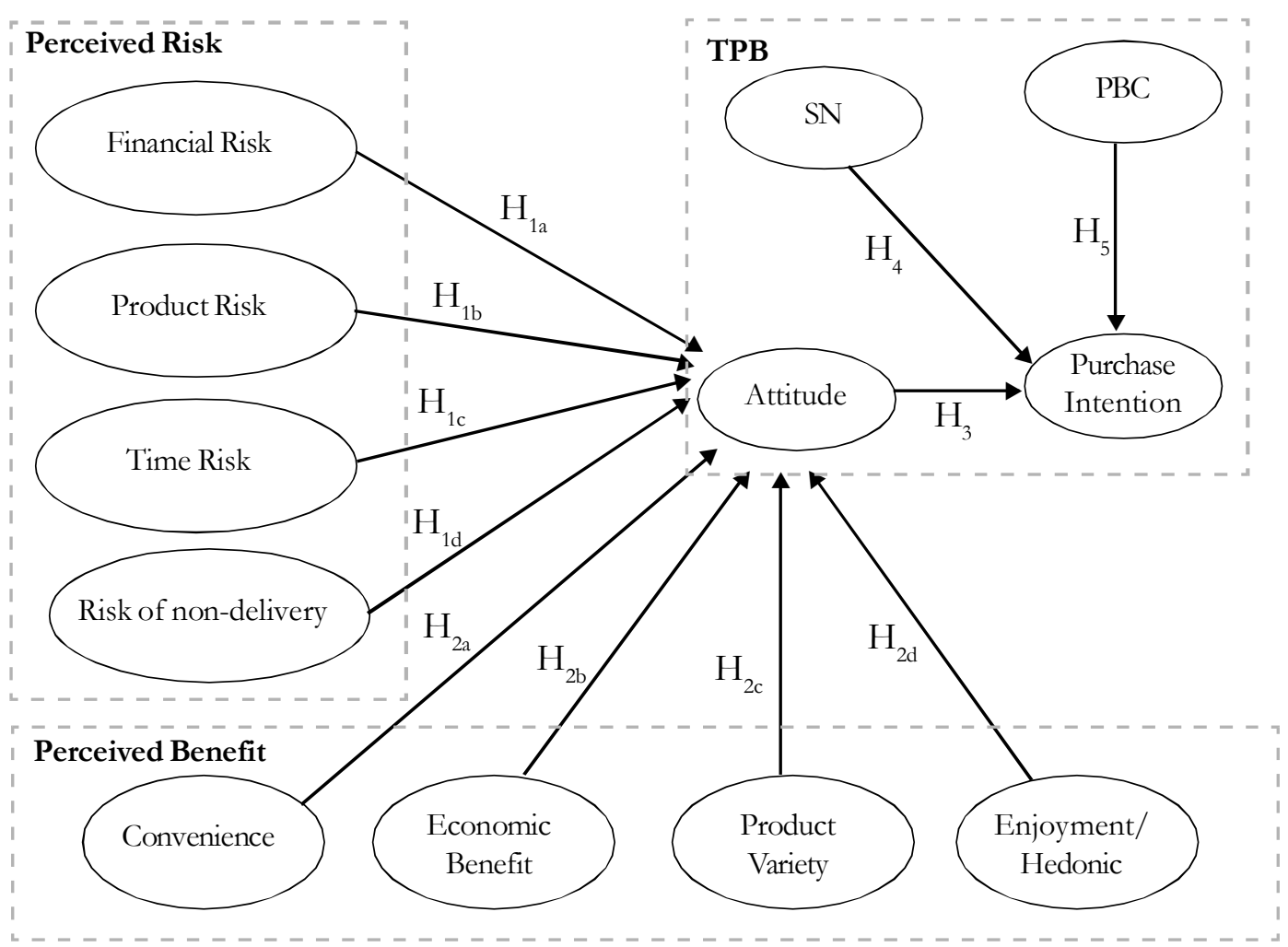




\section{Hypothesis regarding enjoyment/ hedonic benefit}

The hedonic dimension of perceived benefit refers to the consumers' intention to seek pleasure and enjoyment while purchasing online (Forsythe et al. 2006). A purchase process that is associated with a greater degree of playfulness or enjoyment leads to a more positive mood and greater purchase satisfaction, which further leads to more impulsive purchasing (Forsythe et al. 2006; Jarvenpaa and Todd 1996). In an online purchase context, consumers go online to seek pleasure, which further leads to a purchase intention (Childers et al. 2001; Dabholkar 1996; Jarvenpaa and Todd 1997). So:

\section{$H_{2 d}:$ Enjoyment/hedonic benefit has a significant positive impact on the consumer's attitude to- ward online purchases.}

\section{Hypothesis regarding attitude and online purchase intention.}

The Theory of Reasoned Action (TRA) (Ajzen and Fishbein 1980; Fishbein and Ajzen 1975) is a well established theory in the area of consumer behavior that claims purchase intention to be a factor of attitude and the subjective norm. The theory was further extended by Aizen (1991), suggesting the consumers' attitude towards a product/service as a key predictor of the consumers' purchase intentions. The theories have been repeatedly used in the online shopping context by various researchers who have supported attitude as an indicator of consumers' purchase intentions. Therefore, it is hypothesized that:

$H_{3}:$ The attitude towards online purchasing positively impacts the online purchase intention.

\section{Hypothesis regarding the subjective norm and purchase intention}

The Theory of Reasoned Action (TRA) (Ajzen and Fishbein 1980; Fishbein and Ajzen 1975) as well as the Theory of Planned Behavior (TPB) (Aizen 1991) depicts that the subjective norm is an important indicator in determining consumers' purchase intentions. The subjective norm is a consumer's perception about how a specific group of people may think about the behavior in question (Aizen 1991). Kumar (2000) also supported the TPB in the online context, and claimed that the subjective norm influences a consumer's intention to purchase online. Therefore, it is hypothesized that:

$H_{4}$ : The Subjective Norm (SN) positively impacts the online purchase intention.

\section{Hypothesis regarding $P B C$ and consumer intention to purchase online.}

As mentioned earlier PBC refers to the people's perception of the ease or difficulty of possessing the resources and opportunities needed to engage in a behavior (Aizen 1991). Kumar (2000) used TPB in an online purchase context to predict the behavioral intentions of consumers. The research supported that perceived behavioral controls negatively impacted the consumers' behavioral intentions. Other research conducted by Pavlou and Fygenson (2006), with the objective of understanding electronic commerce's adoption, extended the TPB to study and predict two key online consumers' behaviors, i.e. getting information through online retail sites and purchasing products online. The model so developed claimed that online product purchasing is predicted by the purchase intention and perceived behavioral con- 
trol. As per the research findings, attitude and PBC majorly influenced the online purchase intention (explaining 59\% variance in the purchase intention in the research). Similar findings were also suggested by Lee and Ngoc (2010). Therefore we can hypothesize:

H5: Perceived Behavioral Control (PBC) negatively impacts the intention toward online purchases.

\section{Methods}

The questionnaire for the study was divided in two sections. The first section seeks basic information regarding the respondents' demographic characteristics, which includes their age, gender, income, frequency of internet usage and how frequently they purchase items online. The second section of the questionnaire comprises of items to measure the Perceived Risk (PR), Perceived Benefit (PB), Subjective Norm (SN), Perceived Behavioral Control (PBC), Attitude (A) and Intention (I) of the respondents towards online purchasing. All the items were measured on a 5 point Likert scale ranging from $1=$ strongly disagree to $5=$ strongly agree. Items of the perceived risk and perceived benefit were adopted from the scale of Swinyard and Smith (2003); Forsythe et al. (2006) and Ramus and Nielsen (2005); Forsythe et al. (2006) respectively, with four items for each construct. The three items for the subjective norm and the three items for perceived be-

Table 3. Descriptive Statistics

\begin{tabular}{lll}
\hline Basis & Frequency & Percentage \\
\hline Age & & \\
$18-25$ & 108 & 23.1 \\
$25-30$ & 166 & 35.5 \\
$30-35$ & 67 & 14.3 \\
$35-40$ & 74 & 15.8 \\
40-50 & 30 & 6.4 \\
50 above & 23 & 4.9 \\
& & \\
Gender & & \\
Male & 291 & 62.2 \\
Female & 177 & 37.8 \\
& & \\
Monthly Income & & 19.6 \\
Less than 20,000 & 92 & 38.6 \\
20,000-40,000 & 181 & 14.9 \\
40,000-60,000 & 70 & 11.5 \\
60,000-80,000 & 71 & \\
Above 80,000 & 54 & \\
\hline
\end{tabular}


havioral control were adopted from the scale of Wu and Chen (2005). A four item scale to measure attitude was adopted from the scale of George (2004). A further two item scales, to measure the intention to shop online, were adopted from the study of Cheng et al. (2006) and Lai and Li (2005).

The survey was administered via e-mail and social networking sites to approximately 600 students and ex-students of a university in Delhi (India). The convenience sampling method was used in the research. The survey was open from October 1, 2014 to January 31, 2015. Reminder mails were sent to the respondents after every 15 days to minimize any non-response bias. A total of 491 re- sponses were obtained, which were then visually scrutinized for incomplete or duplicate responses. Four hundred and sixty-eight responses were then selected for further research, giving a response rate of 78 percent. The descriptive statistics of the respondents are shown in Table (3)

For the first step of the data's analysis, the content validity of the questionnaire was checked. A pilot survey was conducted on 22 respondents to check the content validity of the questionnaire. All the respondents were academics and can be considered as experts in the related areas. A few suggestions were obtained regarding the phrasing or overall structure of the questionnaire. Most

Table 4. Convergent Validity

\begin{tabular}{|c|c|c|c|c|c|c|}
\hline Factors & Items & $\begin{array}{c}\text { Factor } \\
\text { Loading }\end{array}$ & $\begin{array}{c}\text { T- } \\
\text { Value }\end{array}$ & $\begin{array}{l}\text { Composite } \\
\text { Reliability }\end{array}$ & $\begin{array}{l}\text { Average } \\
\text { Variance } \\
\text { Extracted }\end{array}$ & $\begin{array}{c}\text { Cronbach's } \\
\text { Alpha }\end{array}$ \\
\hline $\begin{array}{l}\text { Risk of time } \\
\text { loss (TR) }\end{array}$ & $\begin{array}{l}\text { TR1 } \\
\text { TR2 } \\
\text { TR3 } \\
\text { TR4 }\end{array}$ & $\begin{array}{l}0.842 \\
0.774 \\
0.785 \\
0.826\end{array}$ & $\begin{array}{l}41.460 \\
42.904 \\
43.321 \\
42.954\end{array}$ & 0.882 & 0.651 & 0.882 \\
\hline $\begin{array}{l}\text { Product } \\
\text { Performance } \\
\text { Risk (PR) }\end{array}$ & $\begin{array}{l}\text { PR1 } \\
\text { PR2 } \\
\text { PR3 } \\
\text { PR4 }\end{array}$ & $\begin{array}{l}0.842 \\
0.781 \\
0.774 \\
0.782\end{array}$ & $\begin{array}{l}43.047 \\
48.829 \\
44.404 \\
42.681\end{array}$ & 0.873 & 0.632 & 0.870 \\
\hline $\begin{array}{l}\text { Delivery Risk } \\
\text { (DR) }\end{array}$ & $\begin{array}{l}\text { DR1 } \\
\text { DR2 } \\
\text { DR3 } \\
\text { DR4 }\end{array}$ & $\begin{array}{l}0.791 \\
0.873 \\
0.850 \\
0.709\end{array}$ & $\begin{array}{l}36.394 \\
40.963 \\
43.184 \\
39.443\end{array}$ & 0.882 & 0.653 & 0.879 \\
\hline $\begin{array}{l}\text { Financial } \\
\text { Risk (FR) }\end{array}$ & $\begin{array}{l}\text { FR1 } \\
\text { FR2 } \\
\text { FR3 } \\
\text { FR4 }\end{array}$ & $\begin{array}{l}0.803 \\
0.795 \\
0.897 \\
0.773\end{array}$ & $\begin{array}{l}52.827 \\
52.496 \\
49.097 \\
51.106\end{array}$ & 0.890 & 0.670 & 0.890 \\
\hline $\begin{array}{l}\text { Convenience } \\
\text { Benefit (CB) }\end{array}$ & $\begin{array}{l}\text { CB1 } \\
\text { CB2 } \\
\text { CB3 } \\
\text { CB4 }\end{array}$ & $\begin{array}{l}0.646 \\
0.796 \\
0.770 \\
0.625\end{array}$ & $\begin{array}{l}76.677 \\
73.012 \\
69.264 \\
67.483\end{array}$ & 0.792 & 0.509 & 0.791 \\
\hline $\begin{array}{l}\text { Economic } \\
\text { Benefit (EB) }\end{array}$ & $\begin{array}{l}\text { EB1 } \\
\text { EB2 } \\
\text { EB3 }\end{array}$ & $\begin{array}{l}0.801 \\
0.810 \\
0.758\end{array}$ & $\begin{array}{l}48.787 \\
52.423 \\
49.476\end{array}$ & 0.833 & 0.624 & 0.832 \\
\hline
\end{tabular}


Table 4. Continued

\begin{tabular}{|c|c|c|c|c|c|c|}
\hline Factors & Items & $\begin{array}{c}\text { Factor } \\
\text { Loading }\end{array}$ & $\begin{array}{c}\text { T- } \\
\text { Value }\end{array}$ & $\begin{array}{l}\text { Composite } \\
\text { Reliability }\end{array}$ & $\begin{array}{c}\text { Average } \\
\text { Variance } \\
\text { Extracted }\end{array}$ & $\begin{array}{c}\text { Cronbach's } \\
\text { Alpha }\end{array}$ \\
\hline $\begin{array}{l}\text { Variety } \\
\text { Benefit (VB) }\end{array}$ & $\begin{array}{l}\text { VB1 } \\
\text { VB2 } \\
\text { VB3 } \\
\text { VB4 }\end{array}$ & $\begin{array}{l}0.866 \\
0.862 \\
0.882 \\
0.871\end{array}$ & $\begin{array}{l}45.875 \\
48.837 \\
48.703 \\
47.103\end{array}$ & 0.926 & 0.758 & 0.926 \\
\hline $\begin{array}{l}\text { Enjoyment/ } \\
\text { Hedonic } \\
\text { Benefit (HB) }\end{array}$ & $\begin{array}{l}\text { HB1 } \\
\text { HB2 } \\
\text { HB3 } \\
\text { HB4 }\end{array}$ & $\begin{array}{l}0.758 \\
0.771 \\
0.756 \\
0.827\end{array}$ & $\begin{array}{l}63.684 \\
64.407 \\
63.959 \\
56.879\end{array}$ & 0.860 & 0.606 & 0.860 \\
\hline Attitude (Att) & $\begin{array}{l}\text { Att1 } \\
\text { Att2 } \\
\text { Att3 } \\
\text { Att4 }\end{array}$ & $\begin{array}{l}0.858 \\
0.784 \\
0.970 \\
0.981\end{array}$ & $\begin{array}{l}42.307 \\
46.549 \\
44.117 \\
42.772\end{array}$ & 0.945 & 0.814 & 0.943 \\
\hline $\begin{array}{l}\text { Intention } \\
\text { (Int) }\end{array}$ & $\begin{array}{l}\text { Int1 } \\
\text { Int } 2\end{array}$ & $\begin{array}{l}0.982 \\
0.979\end{array}$ & $\begin{array}{l}48.105 \\
46.318\end{array}$ & 0.980 & 0.985 & 0.862 \\
\hline $\begin{array}{l}\text { Perceived } \\
\text { Behavioral } \\
\text { Control } \\
\text { (PBC) }\end{array}$ & $\begin{array}{l}\text { PBC1 } \\
\text { PBC2 } \\
\text { PBC3 }\end{array}$ & $\begin{array}{l}0.668 \\
0.788 \\
0.868\end{array}$ & $\begin{array}{l}73.409 \\
63.179 \\
47.733\end{array}$ & 0.821 & 0.606 & 0.820 \\
\hline $\begin{array}{l}\text { Subjective } \\
\text { Norm (SN) }\end{array}$ & $\begin{array}{l}\text { SN1 } \\
\text { SN2 } \\
\text { SN3 }\end{array}$ & $\begin{array}{l}0.767 \\
0.686 \\
0.705\end{array}$ & $\begin{array}{l}49.041 \\
57.713 \\
56.728\end{array}$ & 0.763 & 0.518 & 0.762 \\
\hline
\end{tabular}

of the suggestions were incorporated in the final questionnaire, to make it more comprehensible.

\section{Data Analysis}

To analyze the data and to find the relationship between the different variables, Structural Equation Modeling (SEM) was used. The construct's validity was measured with the help of convergent and discriminant validity before applying SEM over the data.

\section{Convergent Validity}

Convergent validity is the degree to which the multiple items of a construct measure the same thing, or in other words, it is the degree to which each measurement item correlates with its theoretical construct. According to Fornell and Larcker (1981), factor loading, Composite Reliability (CR) and Average Variance Extracted (AVE) need to be measured to identify the convergent validity of the constructs.

According to Hair et al. (1998), factor loading should be statistically significant and should exceed the value of 0.5 for analyzing the reliability indicator. The t-statistics obtained are mentioned in Table (4). Table (4) indicates that the factor loading of all the items is significant and is in the range of 0.608 to 0.981 . In order to evaluate the construct's reliability two indicators were used, namely Composite Reliability (CR) and Cronbach's 


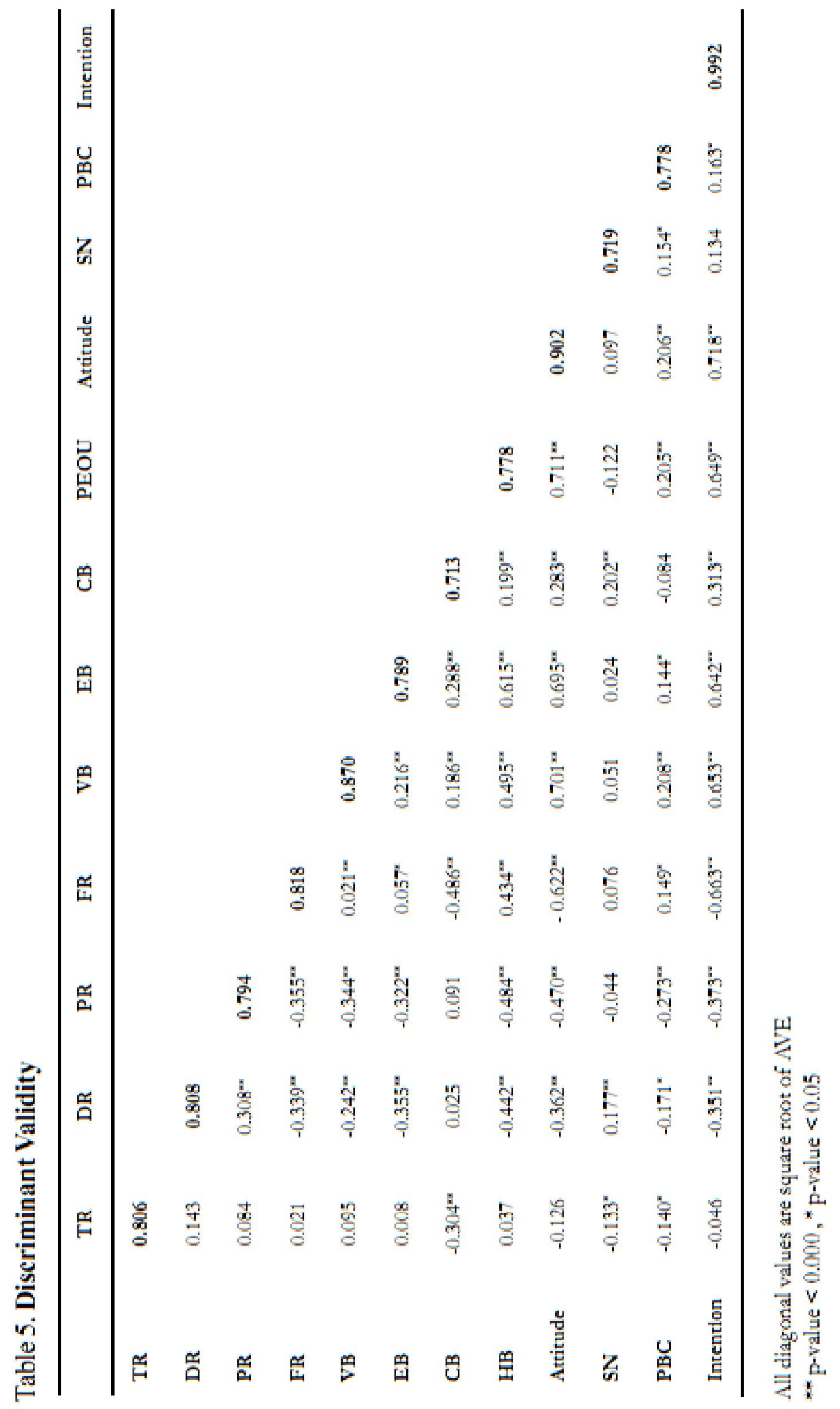


alpha. As indicated in Table (4) the CR and Cronbach's alpha for each construct exceeded the value of 0.8 giving evidence of the internal consistency.

Average Variance Extracted (AVE) is the amount of variance that is indicated by the multiple items of the constructs. According to Hair et al. (2010), the AVE for any construct should be greater than 0.5 and as indicated in Table (4), the AVE ranges between $0.509-0.985$.

\section{Discriminant Validity}

The discriminant validity is the extent to which a construct differs from the other constructs and their indicators. As per Fornell and Larcker (1981), the correlations between any two constructs should be lower than the square root of the variance shared by the items within a construct. As indicated in Table (5) all the diagonal values indicating the square root of AVE are higher than almost all the correlations between any two constructs.

\section{Analysis of Model fit}

The chi-square test was used to assess the overall fit of the model. As claimed by Bentler and Bonnett (1980), chi square statistics are highly sensitive to the sample size and therefore chi square divided by the degree of freedom is suggested as a better fit metric. For the model under study $X^{2} / \mathrm{df}$ $=3.69(\mathrm{p}<0.001)$ suggesting an acceptable model fit. Other fit indices (GFI, CFI, NFI and RMSEA) were also calculated to examine the overall fit of the model. The Goodness of Fit Index (GFI) for the model is 0.91, the Comparative Fit Index (CFI) is 0.93 and the Normed Fit Index (NFI) is 0.95. As per Hair et al. (1998), a GFI, CFI and NFI of greater than 0.9 indicates a good model fit.

Figure 2. Estimates of Structural Equation Modeling

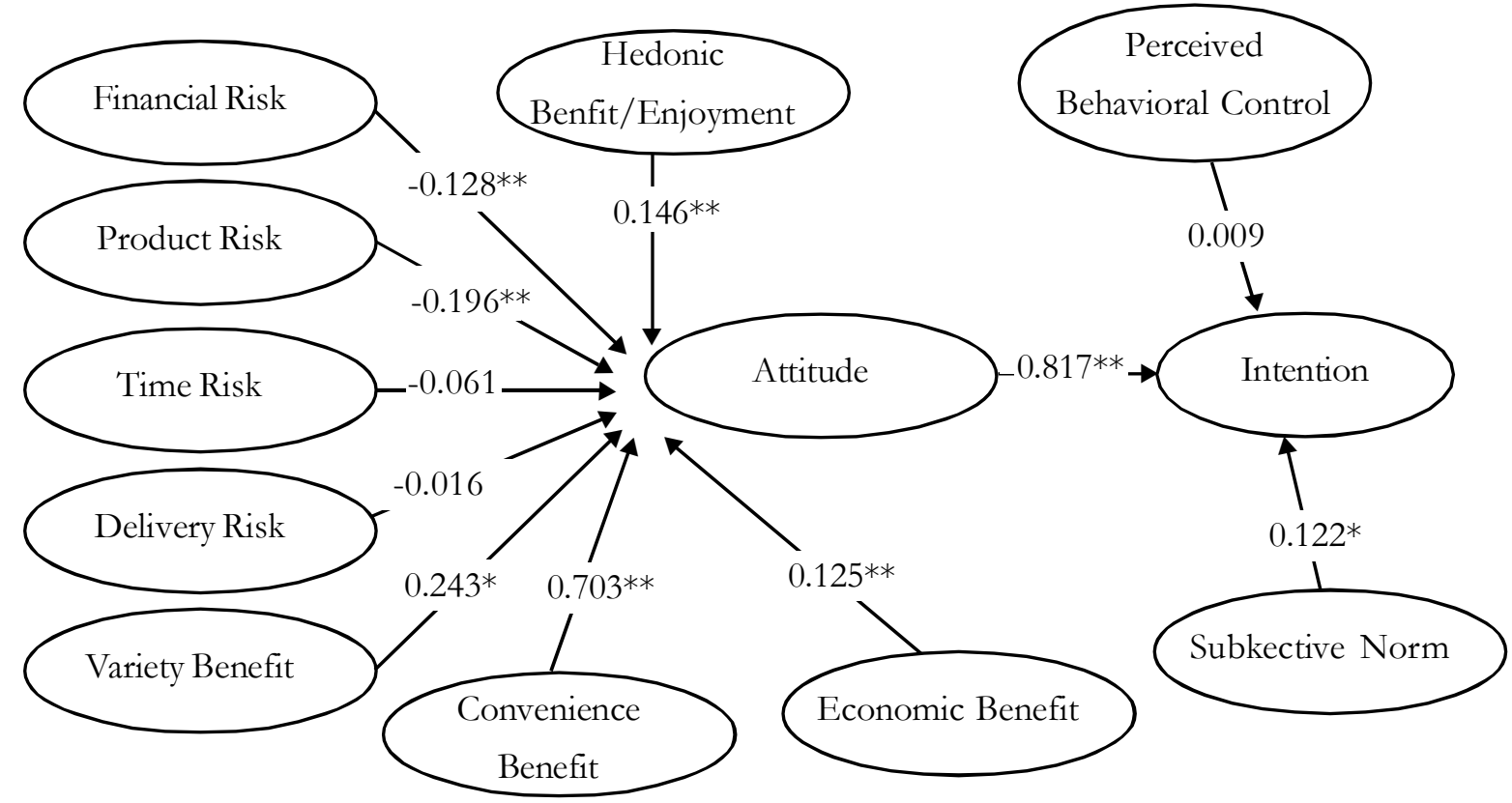


The Root Mean Square Error of Approximation (RMSEA) is 0.06, which also indicates an acceptable model fit (Hair et al. 1998).

\section{Hypothesis Testing}

The analysis of the hypotheses was done with the help of Structural Equation Modeling (SEM). As indicated in Figure 2, the financial risk $(\beta=-0.128, \mathrm{p}<0.001)$ and the product risk $(\beta=-0.196, \mathrm{p}<0.001)$ have a significant negative influence on the attitude toward online purchases, suggesting the acceptance of Hypotheses $H_{1 a}$ and $H^{16}$. The delivery risk and time risk indicated no significant impacts on the attitude towards online purchases $(p>0.05)$ providing no evidence for the acceptance of Hypotheses H1c and $H_{1 d}$ Further, as is evident from Figure 2, the variety benefit $(\beta=0.243, \mathrm{p}<0.001)$, economic benefit $(\beta=0.125, \mathrm{p}<0.001)$, convenience benefit $(\beta=0.703, p<0.001)$ and hedonic benefit $(\beta=0.146, p<0.001)$ all have a significant positive impact on the attitude towards online purchases; thereby suggesting the acceptance of Hypotheses $H_{2 a}$, $H_{2 b}$ and $H_{2 c}$ and $H_{2 d^{\circ}} \mathrm{R}^{2}$ for attitude is 0.900 , indicating that 90 percent of the variance of the attitude towards online purchases can be explained by the financial risk, product risk, variety benefit, convenience benefit, economic benefit and hedonic benefit. Attitude $(\beta=0.817, \mathrm{p}<0.001)$ and the subjective norm $(\beta=0.122, \mathrm{p}<0.001)$ have a significant positive impact on online purchases, suggesting the acceptance of Hypotheses $\mathrm{H}_{3}$ and $H_{4}$. The $\mathrm{R}^{2}$ for intention is 0.925 indicating that 92 percent of the variance of the intention to shop online is indicated by the attitude towards online purchases and the subjective norm.

\section{Findings}

The output from the structural equation modeling supports the model presented in Figure 2. The $\mathrm{R}^{2}$ for the attitude towards online purchases is 0.90 and for the intention to purchase online it is 0.925 , both indicate a good explanatory power for the model. This suggests that the model presented in this paper has a relatively high information content. The findings also reveals that the perceived risk and perceived benefit are important predictors of the attitude towards online purchases and the subjective norm and the attitude are important predictors of the intention to purchase online, while perceived behavioral control has little impact on the intention to shop online.

Among the perceived risk's items, product risk is found to have the most significant negative impact on the attitude towards online purchases $(\beta=-0.196)$. This indicates that Indian consumers have little faith in online vendors and are concerned about the quality of the product that will be delivered to them. Being unable to inspect, touch or feel the products is the major cause of their concern. This is in accordance with the findings of Lu et al. (2005); Lee (2009); Masoud (2013) who claimed that the risk that the product will not performance as expected negatively impacts on the attitude towards online purchases. Providing free sample products or branded and standardized products can help in reducing such apprehensions to some extent. The financial risk is the second most important concern that prevents consumers from purchasing products online. The risk of credit card fraud, the misuse of account information or the unwanted blocking 
of funds while making transactions, caused by technological or human errors, are among the most common concerns that consumers undergo while purchasing goods online. The findings are in accordance with Almousa (2011); Bhatnagar and Ghosh (2004) and Lee (2009) who claimed that financial risk has a significant negative relationship with consumers' intentions to shop online.

The result indicates no significant impact by the time risk and delivery risk on the attitude towards online purchases. This may be because the majority of the respondents are in the age group below 30, and therefore are early adopters of technology (Dholakia and Uusitalo 2002). Similar findings were suggested by Moshrefjavadi et al. (2012), and Sinha (2010) who claimed that there is no significant impact by the time or convenience risk on the attitude towards online purchases. The recent trend of under-promising delivery times is fruitful for increasing the customers' satisfaction. Easy payment facilities like cash on delivery further reduce the consumers' hesitation about delivery issues (Moshrefjavadi, et al. 2012). This may be a reason why consumers are less worried about delivery related issues. However this result contradicts the findings of various other researchers (Childer et al. 2001; Forsythe and Shi 2003; Sinha 2010) in the past who have claimed a significant relationship between the convenience risk and the attitude towards online purchases.

The perceived benefits of an online purchase are major indicators of the attitude towards online purchases. As evident from the result, the convenience benefit $(\beta=$ $0.703)$ has the most significant positive impact on the attitude towards online purchases. This indicates that consumers shop online because of the comfort, time and place that online shops provide. This is also evident from the fact that the travel industry, particularly the Indian railway's ticket booking site (IRCTC) is one of the fastest growing sectors in Indian e-commerce, where consumers can book tickets online conveniently at their own comfort, and can save the time which would have otherwise been wasted waiting in long queues. The variety of products and the economic benefits are other important benefits that motivate consumers to shop online. The huge variety, with brands from all over the world, and the price benefits provided by online vendors are attracting consumers towards online shops, and may be an important reason behind the tremendous growth in the online retail segment in the country. The findings are in accordance with the study by Clemes et al. (2014); Delafrooz et al. (2009); Forsythe et al. (2006); and Jarvenpaa and Todd (1997) who claimed a significant positive impact of convenience, variety and economic benefit on the attitude towards online purchases. The enjoyment benefit has a significant impact on the attitude towards online purchases, indicating the fact that Indian consumers like to browse online purchase sites. Browsing online sites, as a recreational activity, often leads to impulsive purchases and hence is a very important factor for e-retailers. The findings of Aizen (1991) and Kumar (2000) suggest that attitude and the subjective norm are important indicators of the intention to shop online.

The study claims no impact of Perceived Behavioral Control (PBC) on the intention to shop online, which contradicts the findings of Pavlou and Fygenson (2006) and Lee and Ngoc (2010). As mentioned in the above section, PBC refers to the people's perception of the ease or difficulty of possessing the resources and opportunities needed to engage in a behavior (Aizen 1991), which for an internet purchase will be a high 
speed internet connection, a device to use (laptops, personal computers or a smart phone), the skill to use the internet and knowledge of the payment methods. In the present scenario, the government and internet service providers are jointly working together to enhance and extend the web facilities. The consumers are more educated and have less hesitation about using computers or the internet. Therefore, consumers no longer find online stores to be difficult to use. Also in the present research, all the respondents were from urban areas, and are educated and internet users. The method of data collection through e-mail itself ensures that the respondents are internet educated. Also, most of the respondents either own personal computers or have easy access to the internet. The result also claims that the Subjective Norm (SN) has a positive impact on the consumers' attitudes or intention to shop online. The finding is in accordance with Pavlou and Fygenson (2006) and Kumar (2000) who claimed the subjective norm was an important influence in determining consumers' purchasing intentions

\section{Implication and Limitations}

There are several factors that impact on the consumers' online purchase intentions. Consumers expect to be offered a choice and be able to exert control over their purchasing decisions (Kozinets 2004). It is therefore of the utmost importance that online retailers understand their customers. As per the study, the product risk is the most important concern among online consumers. Consumers have little trust in virtual retailers and the quality of the products they offer. A few online retailers, like first cry.com and Amazon have physical outlets as well. Consumers can physically inspect the products be- fore buying. A physical outlet creates trust among consumers, not only about the quality of the products offered but also in the retailers. Business models like brick and clicks that allow customers to pick their products from a nearby store are also helpful in reducing consumers' concerns, to some extent. Cash on delivery is yet another helpful measure to mitigate the perceived financial risk of the consumers.

Variety is an important motivator that brings consumers online. Online retailers like Amazon and Flipkart, with a huge range of products, are among the most successful online retailers in India. This indicates that online buyers hunt for variety and therefore, it is the duty of online retailers to provide a huge range of national and international brands on their sites, so as to facilitate easy comparisons and a more pleasant purchasing experience.

The subjective norm has also emerged as an important influence on the online purchase intention in this study. This implies that online consumers value the opinions of others. An online consumer may look for reviews and ratings before making an online purchase. Recommendations on social networking websites can be fruitful. Also, online websites need to keep a good tack of the reviews and ratings for their products. Products that receive bad reviews for quality should be abandoned, to maintain the reputation of the website. Reviews about delays in delivery or any other service issues need to be taken care of.

Like every piece of research, this study also has a few limitations. One of them is in the process of the data's collection. The email method was used for data collection, to ensure the acquaintance of the respondents with the internet, but this decreased the re- 
sponse rate. Also respondents are from the urban areas of the country, educated and mostly young and middle aged. The findings would have been different if a rural sample was also included.

\section{Conclusion}

This paper focuses on analyzing the relationship between perceived risk and perceived benefit on the attitude, and the impact of attitude, the subjective norm and perceived behavioral control on the intention to make online purchases. The survey of 468 respondents, who were also online users, revealed that there is a negative relationship between product risk and financial risk and the attitude toward online purchases, while convenience, product variety, economic benefit and hedonic benefit positively impact the consumers' attitude to shopping online. Also the attitude towards online purchases and the subjective norm positively impact the intention to shop online.

The findings of the study have several implications for online retailers. Firstly internet retailers dealing with Indian consumers should take into consideration the risks and benefits that Indian consumers perceive in online purchases and design their strategies accordingly. Secondly Indian consumers value the opinions of their families, friends and relatives, indicating that a satisfactory comment by people who are close to them will highly influence them as consumers.

\section{References}

Aghekyan-Simonian, M., S. Forsythe, W. S. Kwon, and V. Chattaraman. 2012. The role of product brand image and online store image on perceived risks and online purchase intentions for apparel. Journal of Retailing and Consumer Services 19 (2): 325-331.

Ajzen, I. 1991. The theory of planned behavior. Organizational Behavior and Human Decision Processes 50 (2): 179-211.

Ajzen, I., and M. Fishbein. 1980. Understanding Attitudes and Predicting Social Behaviour. Prentice Hall.

Akbar, S., and P. T. J. James. 2014. Consumers' attitude towards online purchase factors influencing employees of crazy domains to shop online. Journal of Management and Marketing Research 14: 1.-10. Available online at http://www.aabri.com/manuscripts/131640.pdf.

Al Kailani, M., and R. Kumar. 2011. Investigating uncertainty avoidance and perceived risk for impacting Internet buying: A study in three national cultures. International Journal of Business and Management 6 (5): 76-92.

Al Karim, R. (2013). Customer satisfaction in online purchase: A study into the reasons for motivations and inhibitions. Journal of Business and Management 11 (6): 13-20.

Almousa, M. 2011. Perceived risk in apparel online purchase: A multi dimensional perspective. Canadian Social Science 7 (2): 23-31.

Annual Report IAMAI 2012-2013. Available at http://www.iamai.in/pdf/ AnnualReport201314LowRes.pdf last accessed on 5th January 2014.

Bentler, P. M. and D. C. Bonnet. 1980. Significance tests and goodness of fit in the analysis of covariance structures. Psychological Bulletin 88 (3): 588-606.

Bhatnagar, A., S. Misra, and H. R. Rao. 2000. On risk, convenience, and internet purchase behavior. Association for computing machinery. Communications of the ACM 43 (11): 98-110. 
Bhatnagar A., and S. Ghosh. 2004. A latent class segmentation analysis of e-shoppers. Journal of Business Research 57 (7);758-767.

Chang, M. K., W. Cheung, and V. S. Lai. 2005. Literature derived reference models for the adoption of online purchase. Information and Management 42 (4): 543-559.

Chen, S., and J. Li. 2009. Factors influencing the consumers' willingness to buy in e-commerce . E-Business and Information System Security (EBISS'09). International Conference on IEEE (May): 1-8.

Cheng T. C. E., D. Y. C. Lam, A. C. L. Yeung. 2006. Adoption of internet banking: An empirical study in Hong Kong. Decision Support System 42 (3): 1558-1572.

Chiang, K. P., and R. R. Dholakia. 2003. Factors driving consumer intention to shop online: An empirical investigation. Journal of Consumer Psychology 13 (1):177-183.

Childers,T. L., C. L. Carr, J. Peck. and S. Carson. 2001. Hedonic and utilitarian motivations for online retail purchase behavior. Journal of Retailing 77 (4): 511-535.

Claudia, I. 2012. Perceived risk when buying online: Evidence from a semi-structured interview. Economics Series $22(2):$ 63-73.

Clemes, M. D., C. Gan, and J. Zhang. 2014. An empirical analysis of online purchase adoption in Beijing, China. Journal of Retailing and Consumer Services 21 (3): 364-375.

Crespo, Á. H., I. Rodríguez del Bosque, and M. M. García de los Salmones Sánchez. 2009. The influence of perceived risk on internet purchase behavior: A multidimensional perspective. Journal of Risk. Research 12 (2): 259-77.

Dabhade, A. 2008. Antecedents of older consumers' internet purchase for apparel products: Perceived risk and benefits and purchase orientation. Doctoral Dissertation. Auburn University.

Dabholkar, P. A. 1996. Consumer evaluations of new technology-based self-service options: An investigation of alternative models of service quality. International Journal of Research in Marketing 13 (1): 29-51.

Dan, Y., T. Dong, and R. Liu. 2007. Study of types, resources and their influential factors of perceived risks in purchase online. Journal of Dalian University of Technology 28 (2): 13-19.

Darian,J. C. 1987. In-home purchase: Are there consumer segments? Journal of Retailing 63 (2): 163-186.

Delafrooz. N, L. H. Paim, S. A. Haron, M. S. Sidin, and A. Khatibi. 2009. Factors affecting students' attitude toward online purchase. African Journal of Business Management 3 (5): 200-209. Available at doi:10.1016/j.jbusres.2007.06.017 (accessed 11 ${ }^{\text {th }}$ January 2014).

Dholakia, R. R., and O. Uusitalo. 2002. Switching to electronic stores: Consumer characteristics and the perception of purchase benefits. International Journal of Retail and Distribution Management 30 (10): 459-469.

Dillon, T. W., and H. L. Reif. 2004. Factors influencing consumers' e-commerce commodity purchases. Information Technology, Learning and Performance Journal 22 (2): 1-12.

Fishbein, M., and I. Ajzen. 1975. Belief, Attitude, Intention and Behavior: An Introduction to Theory and Research. Massachusetts, Addison-Wesley.

Fornell, C., and D. F. Larcker. 1981. Evaluating structural equation models with unobservable variables and measurement error. Journal of Marketing Res 18 (1): 39-47.

Forsythe, S., C. Liu, D. Shannon, and L. Gardner. 2006. Development of a scale to measure the perceived benefits and risks of online purchase. Journal of Interactive Marketing 20 (2): 55-75.

Forsythe, S. M., and B. Shi. 2003. Consumer patronage and risk perceptions in Internet purchase. Journal of Business Research 56 (11): 867-875. 
Fornell, C., and D. F. Larcker. 1981. Evaluating structural equation models with unobservable variables and measurement error. Journal of Marketing Res 18 (1): 39-47.

George, J. F. 2004. The theory of planned behavior and Internet purchasing. Journal of Internet Research 14 (3): 198-212. Available at http://dx.doi.org/10.1108/10662240410542634.

Hoffman D. L., and T. P. Novak. 1996. Marketing in hypermedia computer-mediated environments: Conceptual foundations. Journal of Marketing 160 (3): 50-68.

Hair J. F, W. C. Black, B. J. Babin, R. E. Anderson, R. L. Tatham. 1998. Multivariate Data Analysis. Upper Saddle River, NJ: Prentice- Hall; (1998).

IBEF. 1997. The rise and rise of E-commerce in India. Available at http://www.ibef.org/download/The-Riseand-Rise-of-E-commerce-in-India.pdf. Last accessed on $9^{\text {th }}$ June 2015.

Javadi, M., H. Dolatabadi, M. Nourbakhsh, A. Poursaeedi, and A. Asadollahi. 2012. An analysis of factors affecting on online purchase behaviour of consumers. International Journal of Marketing Studies 4 (5): 81-90.

Jarvenpaa, S. L., and P. A. 1997. Consumer reactions to electronic purchase on the World Wide Web. International Journal of Electronic Commerce 1 (2): 59-88.

Kalafatis, S. P., M. Pollard, R. East, and M. H. Tsogas. Green marketing and Ajzen's theory of planned behaviour: A cross-market examination. Journal of Consumer Marketing 16 (5): 441-460.

Keeney, R. 1999. The value of Internet commerce to the customer. Management Science 45 (4): 533-542.

Kim, E.Y. and Y. K. Kim. 2004. Predicting online purchase intentions for clothing products. European Journal of Marketing 38 (7): 883-97.

Kim, J., A. M. Fiore, and H. H. Lee. Influences of online store perception, purchase enjoyment, and purchase involvement on consumer patronage behavior towards an online retailer. Journal of Retailing and Consumer Services 14 (2): 95-107.

Kumar, S. 2000. Consumers' Behavioral Intentions Regarding Online Purchase's. University of North Texas (August).

Lai V. S., and H. Li. Technology acceptance model for Internet banking: An invariance analysis. Information Management 42 (2): 373-386.

Lee, M, C. 2009. Factors influencing the adoption of internet banking: An integration of TAM and TPB with perceived risk and perceived benefit. Electronic Commerce Research and Applications 18 (3):130141.

Lee, S. H., and H. T. B. Ngoc. 2010. Investigating the on-line purchase intentions of Vietnamese students: An extension of the theory of planned behavior. World Transactions on Engineering and Tecbnology Education 8 (4): 471-476.

Lu, H. P., C. L. Hsu, and H. Y. Hsu. An empirical study of the effect of perceived risk upon intention to use online applications. Information Management and Computer Security 13 (2): 106-20.

Machlis, S. 1999. Online shoppers want on-time delivery. Computerworld 33 (10): 43.

Maignan, I., and B. Lukas. 1997. The nature and social uses of the internet: A qualitative investigation. Journal of Consumer Affairs 31 (2): 346-371.

Masoud, Y. E. 2013. The effect of perceived risk on online purchase in Jordan. European Journal of Business and Management 5 (6): 76-87.

Miller, N.G. 2000. Retail leasing in a web enabled world. Journal of Real Estate Portfolio Management 6 (2): 167-184. 
Monsuwé, T. P., B. G. C. Dellaert, and K. D. Ruyter. 2004. What drives consumers to shop online? A literature review. International Journal of Service Industry Management 15 (1): 102-121.

Moshrefjavadi, M. H., H. R. Dolatabadi, M. Nourbakhsh, A. Poursaeedi, and A. Asadollahi. 2012. An analysis of factors affecting on online purchase behavior of consumers. International Journal of Marketing Studies 4 (5): 81-98.

Narasimhan, P. 2016. E-commerce industry to cross $\$ 38$ billion this year. ASSOCHAM, The Hindu (January 2). Http://www.thehindu.com/business/ecommerce-industry-to-cross-38-billion-this-yearassocham/article8058892.ece, accessed on January 3, 2016.

Pallab, P. 1996. Marketing on the Internet. Journal of Consumer Marketing 13 (4): 27-39.

Prasad, C., and A. Aryasri. 2009. Determinants of shopper behaviour in e-tailing: An empirical analysis. Paradigmol 13 (1): 73-85.

Pavlou, P. A., and M. Fygenson. 2006. Understanding and predicting electronic commerce adoption: An extension of the theory of planned behavior. MIS Quarterly 30 (1): 15-143.

Ramus, K., and N. A. Nielsen. 2005. Online grocery purchase: What do consumers think?. Journal of Internet Research 15 (3): 335-352.

Reibstein, D. J. 2002. What attracts customers to online stores and what keeps them coming back? Journal of the Academy of Marketing Science 30 (4): 465-473.

Shih, Y-Y., and K. Fang. 2004. The use of a decomposed theory of planned behavior to study Internet banking in Taiwan. Internet Research 14 (3): 213-223.

Sinha, J. 2010. Factors affecting online purchase behavior of Indian consumers. Doctoral Dissertation. University of South Carolina, USA.

Sinha, P., and S. Singh. 2013. Determinants of consumer perceived risk in online purchase - a study. Indian Journal of Marketing 44 (1): 22-32.

Su, D., and H. Xu. 2011. Research on online purchase intention of undergraduate consumer in Chinabased on the theory of planned behavior. International Business Research 4 (1) (January): 86-92.

Swaminathan, V., E. Lepkowska White, and B. P. Rao. 1999. Browsers or buyers in cyberspace? An investigation of factors influencing electronic exchange. Journal of Computer Mediated communication 5 (2).

Swinyard, W. R., and S. M. Smith. 2003. Why people don't shop online: A lifestyle study of the internet. Consumers, Psychology and Marketing 20 (7): 567-597.

Verhoef, P. C., and F. Langerak. 2001. Possible determinants of consumers' adoption of electronic grocery purchase in the Netherlands. Journal of Retailing and Consumer Services 8 (5): 275-285.

Wu, I-L., and J-L. Chen. 2005. An extension of trust and TAM model with TPB in the initial adoption of on-line tax: An empirical study. International Journal of Hum Comput Studies 62 (6): 784-808.

Zhang, L., W. Tan, Y. Xu, and G. Tan, 2012. Dimensions of consumers' perceived risk and their influences on online consumers' purchasing behaviour. Communications in Information Science and Management Engineering 2 (7): 8-14. 